\title{
Physical activity interventions to improve daily walking activity in cancer survivors
}

\author{
Ruud H Knols ${ }^{1}$, Eling D de Bruin ${ }^{2 *}$, Kei Shirato ${ }^{2}$, Daniel Uebelhart ${ }^{1}$, Neil K Aaronson ${ }^{3}$
}

\begin{abstract}
Background: Cancer patients may benefit from physical exercise programs. It is unclear, however, how sustained levels of physical activity are best achieved in this population. A systematic review was performed to summarize the current evidence of the effect of physical activity interventions on daily walking activity enhancement in cancer survivors, and to review the literature for its methodological quality.

Methods: A search in Medline, PEDro and the Cochrane databases was performed for English literature citations (randomized controlled trials; 'RCTs'). In a first step, one reviewer abstracted data from the included studies on patients, physical activity interventions and outcomes. Two independent reviewers reviewed the methodological quality of these studies. Data were pooled using random-effects calculations.
\end{abstract}

Results: Our search identified 201 citations. Five RCTs that reported changes in daily step activity over time were identified, and were reviewed for methodological quality and substantive results. The median score across studies for methodological quality based on the PEDro criteria was 8 . These 5 RCTs evaluated 660 participants with a mean age of 53.6 (SD 4.2) years. The mean change in daily step activity for patients with a physical exercise intervention was 526 daily steps (SD 537), with a range from -92 to 1299 daily steps. The data of three studies reporting the effect of combined physical activity and counseling on daily walking activity in breast cancer survivors were pooled, however; the $I^{2}$ was $79 \%$, indicating statistical heterogeneity between the three trials.

Conclusion: The 5 RCTs reviewed were of good methodological quality. Together they suggest that combined physical activity and counseling improves daily step activity in (breast) cancer survivors. Studies that define a step goal appear to be more effective in improving daily walking activity than studies that do not do so. However, the current results should be interpreted with caution because of the observed clinical and statistical heterogeneity. Future studies are warranted to evaluate the effects of goal targeted physical activity, with or without counseling, on daily walking in various cancer populations.

\section{Background}

Cancer is increasingly being viewed as a chronic illness requiring long-term management, and thus there is a growing need for evidence-based rehabilitation interventions for cancer survivors [1]. Physical exercise programs have been developed with the aim of improving a range of outcomes, including physical performance, body composition, hemoglobin concentration, immune function, fatigue, psychological well-being and health-related quality-of-life (HRQOL) [2-4]. There is increasing evidence that cancer patients (e.g., breast, colon, and prostate cancer, hematological malignancies) [5,6] may benefit

\footnotetext{
* Correspondence: debruin@move.biol.ethz.ch

${ }^{2}$ Institute of Human Movement Sciences and Sport, ETH Zurich, Zurich, Switzerland
}

from physical exercise programs in terms of improvement in fitness levels, physical activity and HRQOL [7].

Walking is a major component of daily physical activity, and is the most common form of exercise [8]. Walking is self regulated in intensity, duration and frequency, and can be an important indicator of a person's health and fitness status [9]. Among healthy individuals, 10,000 steps daily have been estimated to be of value in maintaining desired health benefits [10]. For cancer survivors, however, it is unclear whether an increase in walking activity results in enhanced functional health.

Improved functional status is a primary goal in the rehabilitation of cancer survivors [11]. Relatively new techniques allowing unobtrusive long-term activity monitoring (e.g., with the use of pedometers or 
microprocessor-based accelerometer recorders) may provide a clearer indication of how much an individual actually walks in daily life [12]. Two reports indicate that the use of activity monitors may significantly increase physical activity levels among children and adolescents [13], as well as in adults [14] with and without chronic health conditions. One report described expected values for daily walking activity in breast cancer patients, and hypothesized that such activity monitoring may facilitate physical activity in this population [15]. Although the evidence on the effect of physical activity interventions on daily step activity in cancer survivors has not been established, activity monitors have recently experienced a surge in popularity as a tool for motivating patients and monitoring physical activity $[14,16]$.

We conducted a systematic review to summarize the currently available evidence from randomized clinical trials (RCT's) on the effect of physical activity interventions on quantified daily walking behavior in cancer survivors. The secondary aim was to evaluate the methodological quality of these studies.

\section{Methods}

\section{Data sources and search strategies}

Individualized search strategies for the Medline, Cochrane and PEDro databases were developed in collaboration with a librarian from the Eidgenössisch Technische Hochschule (ETH), Zurich. We used medical subheadings as search terms, including behavior, cancer, neoplasm, chronic disease, monitoring, motor activity, physical activity interventions, physical exercise, physical therapy modalities, physical therapy techniques, yoga, random* or random allocation and the free text words accelerometer, pedometer, step counter, daily steps, physical activity and concealed. We also reviewed the bibliographies of retrieved articles and relevant conference proceedings. Searches were performed in all databases up to November 2009.

\section{Study selection}

A study was considered eligible for inclusion in the review when it was a RCT, examining the results of a physical activity intervention on daily walking activity in cancer patients. Physical activity interventions were defined as walking, physical exercise, counseling, yoga, relaxation or a combination of these. Studies that evaluated the effectiveness of drugs, nutrition, transcutaneous electrical stimulation and mineral or vitamin supplements were excluded from this review. Studies had to have made use of pedometers, step counters or accelerometers that monitored daily walking activity. We excluded studies of hospitalized patients. The review was limited to English language publications.

\section{Data extraction}

\section{Methodological quality}

Two reviewers (EDB and KS) independently assessed the methodological quality of the studies according to the PEDro scale. The PEDro scale is based on the Delphi list developed by Verhagen et al. [17], which is a set of 11 criteria for quality assessment: 1) eligibility; 2) use of randomization; 3) concealment of treatment allocation; 4) equivalence (or similarity) of groups at baseline; 5) blinding of the subjects; 6) blinding of the therapists, 7) blinding of the outcome assessors; 8) intention-to-treat analyses; 9) reporting of point estimates; 10) measures of variability of the primary outcome and 11) adequacy of follow-up and use of between-group statistical comparisons [18]. Two of the three criteria relating to the use of blinding procedures were not rated because it is difficult, if not impossible, to blind patients and care providers to treatment assignment in this area of research [19]. Thus, nine of the eleven quality criteria were evaluated in this systematic review. For each quality criterion, three rating categories were available: "yes, met criteria"; "no, did not meet criteria"; and "do not know."

Percentage agreement and Cohen's kappa were calculated with GRAPHPAD software (Version 2002-2005; GRAPHPAD Software Inc, San Diego, Ca), and were interpreted in accordance with Landis and Koch's benchmarks for assessing the agreement between raters: poor $(<0)$, slight $(0.0$ to 0.20$)$, fair $(0.21$ to 0.40$)$, moderate $(0.41$ to 0.60$)$, substantial $(0.61$ to 0.80$)$, and almost perfect (0.81 to 1.0$)$ [20]. Disagreement regarding inclusion of the studies was resolved by consensus between authors (RHK, EDB, KS). As recommended by van Tulder et al., [21] a third reviewer (DU) was used in the event of any disagreement between the two reviewers regarding the methodological quality of a trial. The PRISMA-statement was followed for reporting items of this systematic review and meta-analyses [22].

\section{Content of the studies}

One author (RHK) independently abstracted the following information from each of the studies included in this review: 1) design and sample; 2) inclusion criteria; $3)$ type of intervention; 4) type of walking activity monitoring system; 5) change in steps per day; and 6) conclusions from the studies and statistical significance. In case a study reported both immediate post-intervention and follow-up data, we reported the post-intervention data.

\section{Data synthesis and analysis}

The study results were pooled, if appropriate, using a random effects model after evaluating heterogeneity. Heterogeneity of the study findings was assessed with the $\mathrm{I}^{2}$ statistic, where a value greater than $50 \%$ is considered to indicate substantial heterogeneity [23]. For 
continuous daily step outcomes, the effect-size and its $95 \%$ CI were reported when data were on a uniform scale. For the summary effect size, we assessed statistical heterogeneity by calculating the Q-statistic. An effect size with a two-sided probability of less than 0.05 was deemed to be heterogeneous. Publication bias was tested using the fail-safe $\mathrm{N}$, which signifies the number of studies that would be required to change a significant summary effect to one that was not statistically significant [14]. Comprehensive Meta-analyses software (BIOSTAT, Englewood NJ, USA) was used for the analyses of pooled data.

\section{Results}

Our search identified 201 potentially relevant articles (Figure 1). Four published RCT's [24-27] and one RCT [Knols RH, de Bruin ED, Uebelhart D, Aufdemkampe G, Schanz U, Stenner-Liewen F, Hitz F, Taverna C,

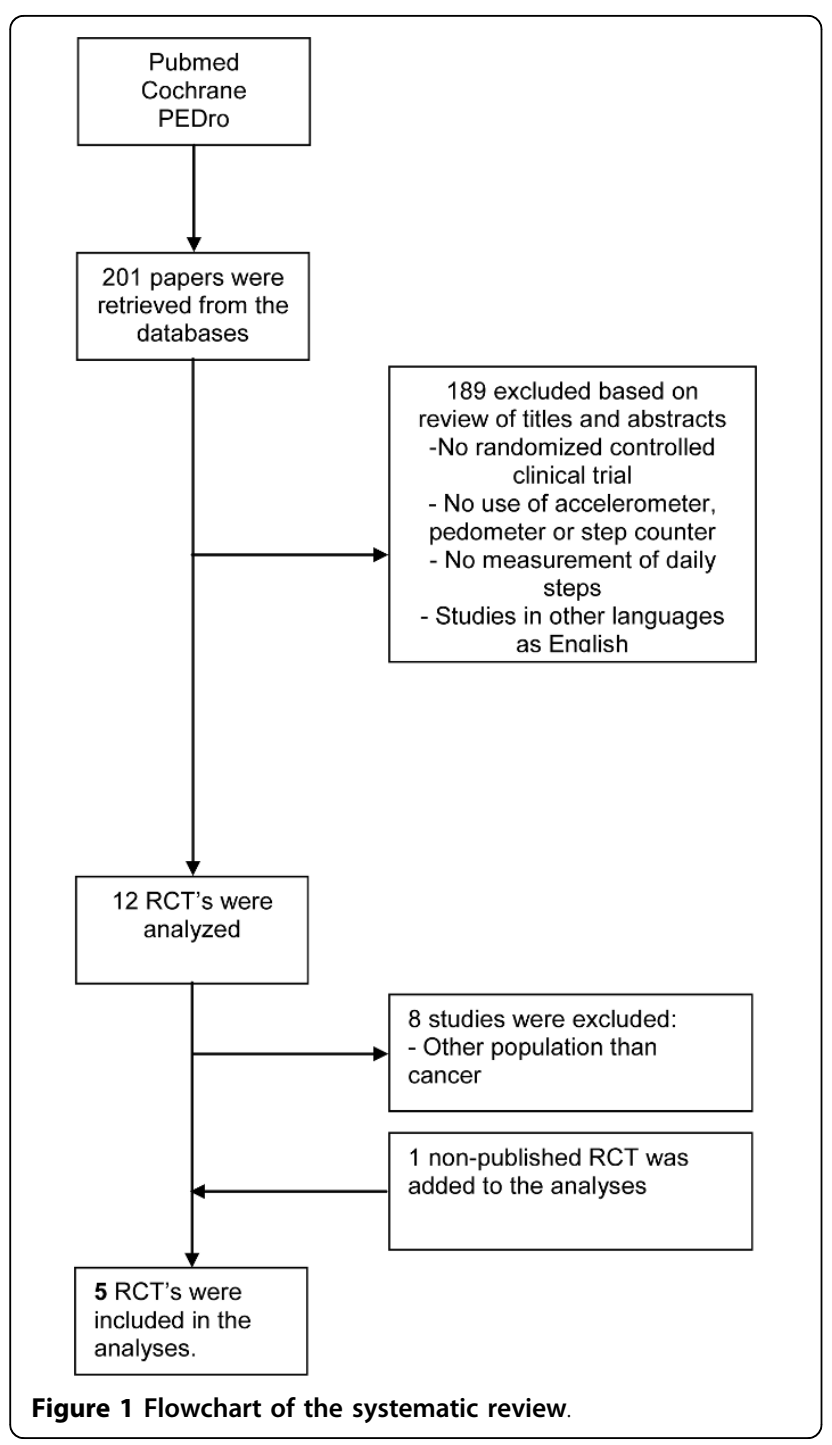

Aaronson NK: Effects of an outpatient physical exercise program in hematopoietic stem-cell transplantation recipients: a randomized clinical trial, unpublished] that was submitted for publication at the time of inquiry, met the eligibility criteria and were included in the final analysis. We identified three $[24,29,30]$ reports from the one Yale Exercise and Survivorship study. Although these three papers focused on different research questions $[24,29,30]$ they essentially were all based on the same set of data for the parameters of interest for this review. Therefore, they were treated as one publication. The report of Irwin et al. [24] was used in this systematic review, as this paper provided means and standard deviations of pedometer steps/day for baseline and posttreatment, that were needed for the meta-analysis.

\section{Methodological quality}

The results of the methodological quality assessment are presented in table 1 . The reviewers agreed on 44 of 45 methodological ratings $(97.8 \%)$. The remaining disagreements were resolved after discussions among the reviewers. The inter-reviewer $\kappa$ statistic was 0.79 (95\% CI, 0.38 to 1.20 ). The median criteria score on the Delphi list (range 1 to 9) was 8 (Table 1 ). The studies of Irwin et al. [24] and Knols et al. [Knols RH, de Bruin ED, Uebelhart D, Aufdemkampe G, Schanz U, StennerLiewen F, Hitz F, Taverna C, Aaronson NK: Effects of an outpatient physical exercise program in hematopoietic stem-cell transplantation recipients: a randomized clinical trial, unpublished] were rated positively on all nine methodological criteria.

All 5 studies [[24-27] \& Knols RH, de Bruin ED, Uebelhart D, Aufdemkampe G, Schanz U, Stenner-Liewen F, Hitz F, Taverna C, Aaronson NK. Effects of an outpatient physical exercise program in hematopoietic stem-cell transplantation recipients: a randomized clinical trial, unpublished] explicitly stated the eligibility criteria employed, reported using an appropriate method to generate the random allocation sequence, reported group similarity at baseline for the most important prognostic indicators, were successful in obtaining at least $85 \%$ of the data for the primary outcome(s), performed an intention-to-treat analysis, provided between group comparisons and provided point estimates and measures of variability for the primary outcome(s). Four of 5 studies reported using an appropriate method to generate concealment of allocation [[24-26] \& Knols RH, de Bruin ED, Uebelhart D, Aufdemkampe G, Schanz U, Stenner-Liewen F, Hitz F, Taverna C, Aaronson NK. Effects of an outpatient physical exercise program in hematopoietic stem-cell transplantation recipients: a randomized clinical trial, unpublished]. The outcome assessors were blinded in 2 of 5 studies [[24] \& Knols RH, de Bruin ED, Uebelhart D, Aufdemkampe 
Table 1 Methodological quality of the included studies

\begin{tabular}{|c|c|c|c|c|c|c|c|c|c|c|}
\hline $\begin{array}{l}\text { Item } \rightarrow \\
\downarrow \text { Study }\end{array}$ & Eligibility & $\begin{array}{c}\text { Randomly } \\
\text { allocated }\end{array}$ & $\begin{array}{l}\text { Concealed } \\
\text { allocation }\end{array}$ & $\begin{array}{c}\text { Similar } \\
\text { at } \\
\text { baseline }\end{array}$ & $\begin{array}{c}\text { Blinding } \\
\text { of } \\
\text { assessors }\end{array}$ & $\begin{array}{c}\text { Measures } \\
\text { from } \\
\text { more } \\
\text { than } 85 \%\end{array}$ & $\begin{array}{c}\text { Intention- } \\
\text { to-treat }\end{array}$ & $\begin{array}{c}\text { Between } \\
\text { group } \\
\text { comparison }\end{array}$ & $\begin{array}{c}\text { Point- } \\
\text { estimates } \\
\text { and } \\
\text { measures } \\
\text { of } \\
\text { variability }\end{array}$ & $\begin{array}{c}\text { Total } \\
\text { items } \\
\text { reported }\end{array}$ \\
\hline Irwin[24] & + & + & + & + & + & + & + & + & + & 9 \\
\hline Rogers [25] & + & + & + & + & $?$ & + & + & + & + & 8 \\
\hline Vallence [26] & + & + & + & + & $?$ & + & + & + & + & 8 \\
\hline Matthews [27] & + & + & - & + & - & + & + & + & + & 7 \\
\hline $\begin{array}{l}\text { [Knols RH, de Bruin ED, } \\
\text { Uebelhart D, } \\
\text { Aufdemkampe G, } \\
\text { Schanz U, Stenner- } \\
\text { Liewen F, Hitz F, } \\
\text { Taverna C, Aaronson NK. } \\
\text { Effects of an outpatient } \\
\text { physical exercise } \\
\text { program in } \\
\text { hematopoietic stem-cell } \\
\text { transplantation } \\
\text { recipients: a randomized } \\
\text { clinical trial, } \\
\text { Unpublished] }\end{array}$ & + & + & + & + & + & + & + & + & + & 9 \\
\hline Total items & 5 & 5 & 4 & 5 & 2 & 5 & 5 & 5 & 5 & \\
\hline
\end{tabular}

+; met criteria on PEDro-scale, -; did not met criteria on PEDro-scale, ?; don't know.

G, Schanz U, Stenner-Liewen F, Hitz F, Taverna C, Aaronson NK. Effects of an outpatient physical exercise program in hematopoietic stem-cell transplantation recipients: a randomized clinical trial, unpublished].

\section{Study characteristics}

In all studies, the participants wore the activity monitors for 7 consecutive days [[24-27] \& Knols RH, de Bruin ED, Uebelhart D, Aufdemkampe G, Schanz U, StennerLiewen F, Hitz F, Taverna C, Aaronson NK: Effects of an outpatient physical exercise program in hematopoietic stem-cell transplantation recipients: a randomized clinical trial, unpublished]. One study reported measurements for 7 days, but included 4 valid days for assessment [25].

Different instruments for measuring physical activity were used across the studies: an Actigraph MTI model 71256 [27], a GT1 M Actigraph accelerometer [25], a Cymatech step activity accelerometer SAM3 [Knols RH, de Bruin ED, Uebelhart D, Aufdemkampe G, Schanz U, Stenner-Liewen F, Hitz F, Taverna C, Aaronson NK: Effects of an outpatient physical exercise program in hematopoietic stem-cell transplantation recipients: a randomized clinical trial, unpublished], and a New lifestyles digi-walker SW-200 [26]. One trial did not report the type accelerometer or pedometer used [24].

The drop-out rate between baseline and post-treatment varied between 0\% [27] and 13\% [Knols RH, de Bruin ED, Uebelhart D, Aufdemkampe G, Schanz U,
Stenner-Liewen F, Hitz F, Taverna C, Aaronson NK: Effects of an outpatient physical exercise program in hematopoietic stem-cell transplantation recipients: a randomized clinical trial, unpublished]. Two studies $[24,26]$ used non-sealed pedometers and instructed the participants to record the daily steps taken at the end of each day of the measurement period. One study used a sealed accelerometer [Knols RH, de Bruin ED, Uebelhart D, Aufdemkampe G, Schanz U, Stenner-Liewen F, Hitz F, Taverna C, Aaronson NK. Effects of an outpatient physical exercise program in hematopoietic stem-cell transplantation recipients: a randomized clinical trial, unpublished].

Two studies $[24,26]$ included a step diary in the activity program and 4 trials included physical activity counseling, [24-27] with a median of 4 counseling sessions (range 4-8 sessions). Three studies were performed in the United States [24,25,27], 1 in Canada [26], and 1 in Switzerland [Knols RH, de Bruin ED, Uebelhart D, Aufdemkampe G, Schanz U, Stenner-Liewen F, Hitz F, Taverna C, Aaronson NK: Effects of an outpatient physical exercise program in hematopoietic stem-cell transplantation recipients: a randomized clinical trial, unpublished].

\section{Patient characteristics}

In total, 660 participants were included in the studies reviewed. Their mean age (SD) was 53.6 (SD 4.2) years. All studies included participants older than 60 years 
[[24-27] \& Knols RH, de Bruin ED, Uebelhart D, Aufdemkampe G, Schanz U, Stenner-Liewen F, Hitz F, Taverna C, Aaronson NK: Effects of an outpatient physical exercise program in hematopoietic stem-cell transplantation recipients: a randomized clinical trial, unpublished].

Across studies, only $11.7 \%$ of the sample was male. Four studies were on breast cancer and enrolled women only [24-27]. One study was with hematopoietic stem cell transplantation recipients [Knols $\mathrm{RH}$, de Bruin ED, Uebelhart D, Aufdemkampe G, Schanz U, Stenner-Liewen F, Hitz F, Taverna C, Aaronson NK: Effects of an outpatient physical exercise program in hematopoietic stem-cell transplantation recipients: a randomized clinical trial, unpublished].

Four studies reported participants' race/ethnicity [24-27]. Across these studies, on average, 71\% was white (SD 32\%). All studies reported participants' education [[24-27] \& Knols RH, de Bruin ED, Uebelhart D, Aufdemkampe G, Schanz U, Stenner-Liewen F, Hitz F, Taverna C, Aaronson NK: Effects of an outpatient physical exercise program in hematopoietic stem-cell transplantation recipients: a randomized clinical trial, unpublished]. The mean (SD) percentage of participants with a college degree or higher was $38 \%$ (SD 15\%). Three studies reported the time since diagnosis $[24,26,27]$. The median time since diagnosis was 2.6 years (SD 1.2 years, range $0.8-3.3$ years). Four studies reported body mass index [[24,26,27], Knols RH, de Bruin ED, Uebelhart D, Aufdemkampe G, Schanz U, Stenner-Liewen F, Hitz F, Taverna C, Aaronson NK: Effects of an outpatient physical exercise program in hematopoietic stem-cell transplantation recipients: a randomized clinical trial, unpublished]: the mean BMI percentage was $27.6 \%$ (SD 3.0\%).

One report described obesity of the participants; 111 of the 377 participants had a BMI >30 (29.4\%); 77 of these 111 patients $(20.4 \%)$ had a BMI between 30.0 and 34.9, 17 (4.5\%) patients had a BMI between 35.0 and 39.9 and 17 patients had a BMI $\geq 40$ [26]. Two studies reported participants to be physically active at baseline. One study reported that one third of the participants performed physical exercise [26], and the other study reported that two-thirds of the participants were physically active for at least 20 minutes per day [24]. On average, across all studies, participants made 6285 steps (SD 1344) per day at baseline, with a range from 4697 to 8178 . The mean change in daily step activity for patients with a physical exercise intervention was 527 daily steps (SD 536, with a range from -92 to 1299 daily steps.

A variety of physical activity modalities were employed: combined supervised endurance training (swimming, aerobics, other forms or a combination) plus individual exercise at a health club [24], walking $[25,27]$, behavior change intervention including discussion groups [25], supervised and home exercise [24,25], face-to-face counseling [25], telephone counseling $[26,27]$, physical activity motivators as a standard public health recommendation [26], a leaflet with information about physical activity [25,26], pedometers [24,26], combined supervised resistance strength and endurance training [Knols RH, de Bruin ED, Uebelhart D, Aufdemkampe G, Schanz U, Stenner-Liewen F, Hitz F, Taverna C, Aaronson NK: Effects of an outpatient physical exercise program in hematopoietic stem-cell transplantation recipients: a randomized clinical trial, unpublished], or combinations of the above (see table 2). Two RCTs reported the intensity of the physical exercise interventions. One trail used an intensity of $60-80 \%$ of the maximum heart rate [24] and one RCT offered exercise up to $75 \%$ of the maximum heart rate [Knols $\mathrm{RH}$, de Bruin ED, Uebelhart D, Aufdemkampe G, Schanz U, StennerLiewen F, Hitz F, Taverna C, Aaronson NK: Effects of an outpatient physical exercise program in hematopoietic stem-cell transplantation recipients: a randomized clinical trial, unpublished]. In one RCT, in the first four weeks, the goal was to walk three times/week (20-30 minutes/session); during week 5-7 to walk four times/ week (30-40 minutes/session), and for the final 5 weeks of the study to walk 5 times/week (30-40 minutes/session) [27]. In one RCT they were advised to perform 30 minutes of moderate walking 5 times a week [25], and in one RCT the patients were advised to perform 30 minutes of vigorous walking 5 times a week [26]. The mean duration of the physical activity programs was 14.4 weeks (SD 5.4), ranging from 12 to 24 weeks.

\section{Effects of physical activity interventions on daily walking}

Two studies yielded statistically significant results for change in daily step counts [24,27]. In these studies $[24,27]$, a part of the program was helping patients to define a step target. Three studies did not achieve statistically significant changes for daily step counts [[25,26], Knols RH, de Bruin ED, Uebelhart D, Aufdemkampe G, Schanz U, Stenner-Liewen F, Hitz F, Taverna C, Aaronson NK: Effects of an outpatient physical exercise program in hematopoietic stem-cell transplantation recipients: a randomized clinical trial, unpublished]. A daily step goal definition was used in only one of these latter studies (table 2) [25]. Two reports from the Yale Exercise and Survivorship study $[28,29]$ provided additional information on the outcome of interest. The participants in the physical exercise group increased their pedometer steps/week, on average by 1621 steps $(11,347$ steps/week [28] or approximately $0.9 \mathrm{miles} /$ day $[28,29]=$ 6.3 miles/week [28]), compared to 85 steps (595 steps/ 


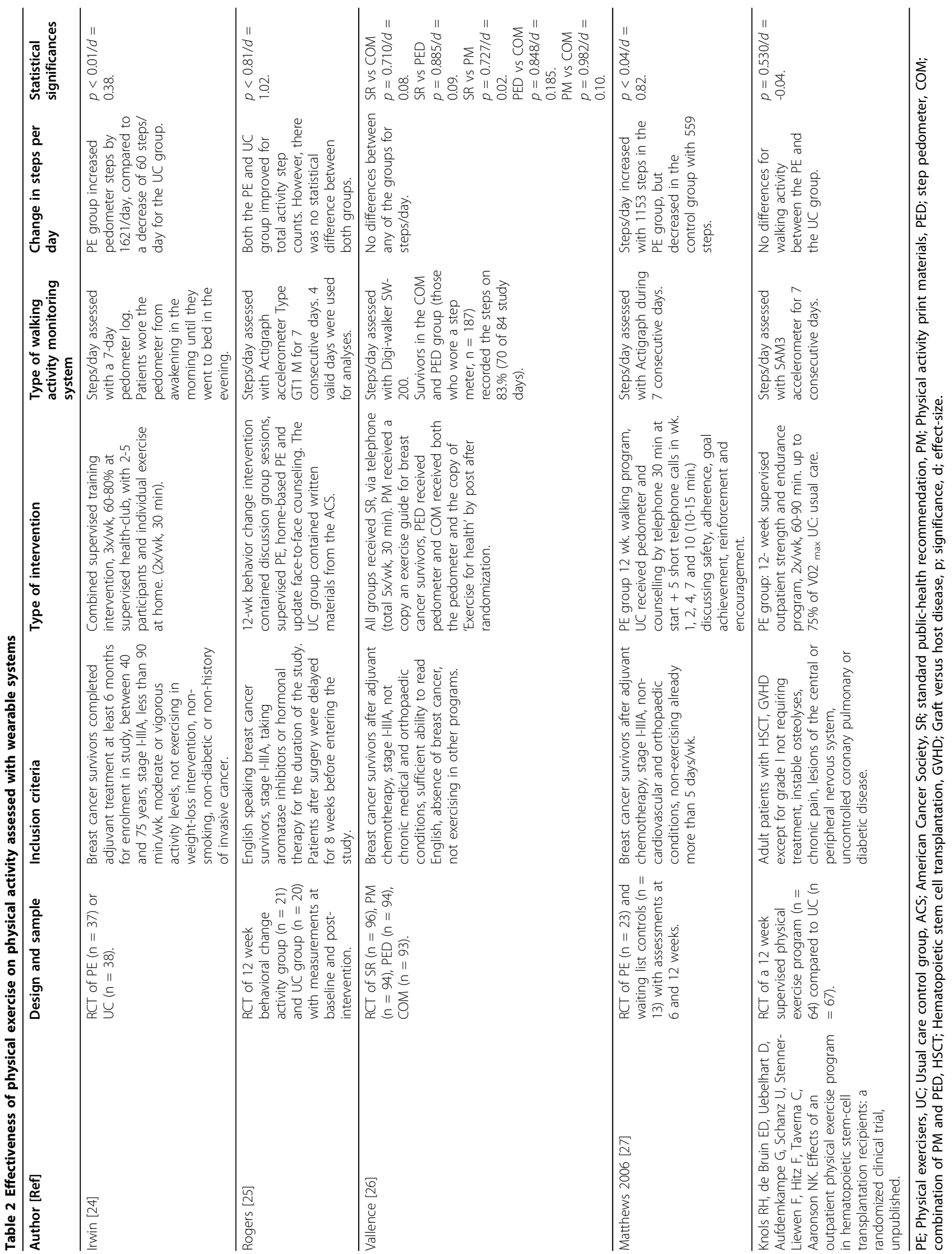


week or approximately 0.05 miles/day [28,29] (0.35 miles/ week) [28] in the usual care group $(\mathrm{p}=0.03)$ [28].

\section{Meta-analyses}

Three RCTs were similar regarding patients, the interventions, and outcomes measures. All three of these studies were with breast cancer patients after primary medical treatment had been completed. All three studies investigated the combined effect of physical activity, counseling and goal setting, and used a usual care control group [24,25,27]. Across these studies, 152 patients were evaluated ( $\mathrm{n}=81$ and 71 in the intervention and control groups, respectively). Their mean age was 54.4 (SD 2.4) years. All three studies included participants older than 60 years. The participants mean daily step average was 6377 steps (SD 822) at baseline, with a range from 5083 to 7409 steps. The duration of the intervention varied between 6 weeks [25] and 6 months [24] for supervised physical activity, and between six weeks of supervised and 10 week home-based activity in another trial [27]. One trial [25] included 10 weeks of home-based activity after the supervised program had been completed. All RCT's offered counseling as part of the program and used a pedometer which was carried at the waist. The patients were asked to record their daily steps to check if they achieved their target goals $[24,25,27]$. The mean change in daily step activity was 1099 daily steps (SD 2136), with a range from 1087 to 3182 steps.

Statistical heterogeneity between the three trials was observed in meta-analyses after pooling; q-value $=9.508$, $\mathrm{df}(\mathrm{Q})=2, p=0.009, \mathrm{I}^{2}=79 \%$ (figure 2). The effect-size (ES) for the three studies combined was $0.4(95 \% \mathrm{CI}$ : lower limit 0.0 , upper limit $0.7, p=0.028$ ). The evaluation of potential publication bias indicated that 2 missing studies would increase the $p$-value to greater than 0.05 .

\section{Discussion}

In this systematic review we evaluated the methodological quality and summarized the substantive results of studies of physical activity interventions for cancer patients designed to increase the level of daily walked steps. Five randomized clinical trials (RCTs) were identified, one satisfied 7 of 9 methodological quality criteria [27], two 8 of 9 criteria [25,26], and two all 9 quality criteria [[24], Knols RH, de Bruin ED, Uebelhart D, Aufdemkampe G, Schanz U, Stenner-Liewen F, Hitz F, Taverna C, Aaronson NK: Effects of an outpatient physical exercise program in hematopoietic stem-cell transplantation recipients: a randomized clinical trial, unpublished]. The most commonly observed problems were the blinding of the assessors and failure to report concealment of allocation (see table 2).

Together the results of these studies suggest that daily walking activity is likely to improve only when a realistic step goal is defined. Two of 5 reports that described a step goal were effective in improving daily step activity $[24,27]$. Conversely, the studies that did not define a step goal were not found to be effective in improving daily step activity [[26], Knols RH, de Bruin ED, Uebelhart D, Aufdemkampe G, Schanz U, Stenner-Liewen F, Hitz F, Taverna C, Aaronson NK: Effects of an outpatient physical exercise program in hematopoietic stemcell transplantation recipients: a randomized clinical trial, unpublished].

The pooled results of the three studies examining the effect of physical activity on daily step activity showed a moderate effect (mean ES $=0.4$ ). A statistically significant difference favouring the implemented exercise

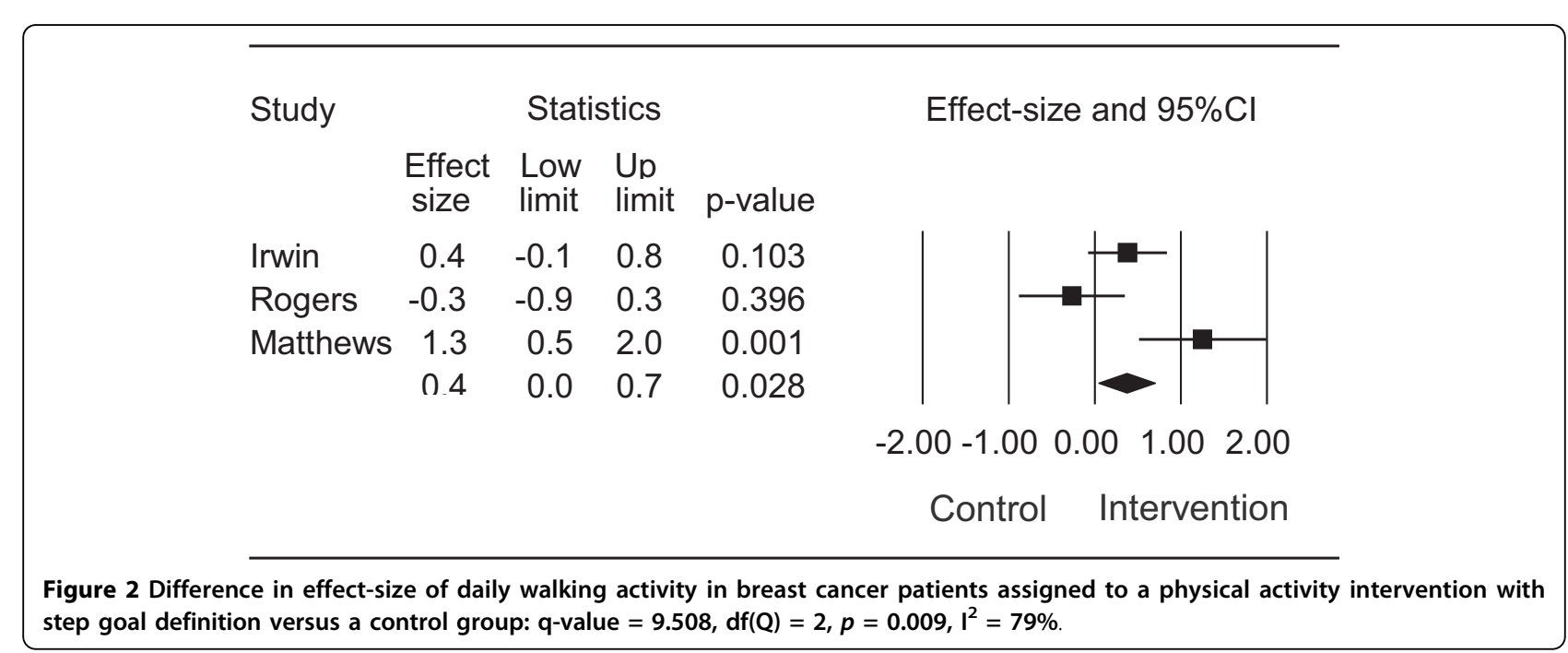


intervention was reported in two of three trials; however, the $\mathrm{I}^{2}$ value was larger than $50 \%$, indicating statistical heterogeneity between the pooled data. Moreover, a publication bias may have influenced the results of the meta-analyses. The evidence suggests that targeted exercise programs with elements of both counseling and goal setting have the potential to increase the daily step activity level.

A noteworthy feature of the trials included in this review was the large variability in study interventions. The diversity in the activities prescribed (e.g., walking, strength and endurance, interventions with or without counseling) reflects the absence of consensus on the optimal activity program for cancer survivors [30]. It is likely that passive interventions such as transcutaneous muscular stimulation are not able to improve daily step activity, although they may be helpful in improving muscle strength [31], exercise capacity [32] and walking performance in laboratory settings [33].

The results of our review are comparable with other reports on programs aimed at improving walking in varied populations. There is increasing evidence that the definition of a step goal may be the key motivational factor in increasing physical activity [14]. Users of activity monitors who were given a goal, whether the 10'000 steps a day goal (as described by Tudor Locke et al.) or a personalized step goal [34], significantly increased their activity over baseline. This was not observed in studies where pedometer users were not given a goal [14].

It is important that cancer survivors are encouraged to meet the public guidelines for physical activity, because higher levels of physical activity are associated with reduced risk of overall mortality, death due to (breast) cancer, and breast cancer recurrence [35]. Recently, one study calculated that the median expected values for breast cancer survivors was 7409 steps/day, as assessed with a pedometer [15]. This is comparable with individuals with type 1 diabetes (8008 steps/day), mental retardation/intellectual disability (7787 steps/day), and HIV patients (7545 steps/day), but higher than for patients with COPD (2237 steps/day) and disabled elderly (1214 steps/day). Breast cancer patients are generally younger and less restricted in their daily physical activity than patients with many other forms of cancer [15]. Thus, not surprisingly, their median expected daily step count is higher than patients with non-small cell lung cancer (5308 steps/day) [31] and hematological cancer (5355 steps/day) [36]. Additional research is needed to determine the daily step values for patients with other forms of cancer, such as prostate, colon or head-and-neck cancer.

In order to facilitate behavior change, it is advocated that interventions be theory-based [37]. The theory of planned behavior (TPB) is a model that has been shown to predict physical activity motivation of breast cancer survivors. A combined approach using goal setting and print materials together with other TPB-based behavior change strategies (e.g. telephone counseling) may represent a promising approach $[37,38]$. Furthermore, social cognitive theory may be a useful framework for future investigations of physical exercise behaviour in cancer survivors [39]. This has been done in a trial of the effect of a pedometer-based telephone intervention on physical activity levels of cardiac patients who did not attend a cardiac rehabilitation program [40]. Yet, RCT's evaluating the effectiveness of the social cognitive theory in cancer survivors is warranted.

\section{Study limitations}

We developed and utilized a structured study protocol to guide our search strategy, study selection, extraction of data and statistical analysis. However, a number of possible limitations of this review should be noted. First, the search strategy was limited to published studies identified through the selected search engines. Second, as noted, a publication bias may have been present, as well as a language bias, given that we restricted our search to English language publications. Third, as there were only 5 randomized trials, we also included several observational studies, the results of which may be affected by confounding bias due to the absence of random assignment. Fourth, many of the studies were small and may have lacked statistical power to demonstrate differences, if such differences were present. Finally, the interventions were of relatively short duration and heterogeneous in their design, and most patients investigated were breast cancer survivors.

\section{Future research}

Despite these limitations, we believe that our review provides useful information regarding the effects of physical activity interventions aimed at improving daily step activity in cancer patients. It also provides some guidance about the components that should explicitly be considered in future interventions to enhance their effect on walking behaviour. Future studies evaluating the effects of physical activity interventions should be large RCTs carried out among diverse populations of cancer survivors. Primary outcomes for such RCTs should, as previously suggested, include both physical activity and detailed evaluation of health outcomes assessed both in the short and longer term [14].

\section{Conclusion}

To the best of our knowledge, this is the first systematic review to include meta-analyses evaluating the effects of physical activity interventions on changes in daily 
walking activity in cancer survivors. Together, the studies reviewed were of relatively high methodological quality. Future studies are warranted to evaluate the effects of goal targeted physical activity, with or without counseling, on daily walking in various cancer survivor populations.

\section{Acknowledgements}

We thank Michelle Schmocker for her assistance in preparing the final manuscript.

\author{
Author details \\ ${ }^{1}$ Department of Rheumatology and Institute of Physical Medicine, University \\ Hospital Zurich, Switzerland. ${ }^{2}$ Institute of Human Movement Sciences and \\ Sport, ETH Zurich, Zurich, Switzerland. ${ }^{3}$ Division of Psychosocial Research and \\ Epidemiology, The Netherlands Cancer Institute, Amsterdam, The \\ Netherlands.
}

\section{Authors' contributions}

$\mathrm{RHK}$ is the guarantor of the study. He designed the study and was the main author of the manuscript. EDB and KS designed and prepared the study protocol, assessed the methodological quality of the studies and critically revised the study and the manuscript for its content. DU initiated the study and reviewed and revised the manuscript. NKA supervised and critically reviewed and revised the study and the manuscript. All authors read and approved the final manuscript.

\section{Competing interests}

The authors declare that they have no competing interests.

Received: 24 February 2010 Accepted: 4 August 2010

Published: 4 August 2010

\section{References}

1. Spence RR, Heesch KC, Brown WJ: Exercise and cancer rehabilitation: A systematic review. Cancer Treat Rev 2009.

2. Knols R, Aaronson NK, Uebelhart D, Fransen J, Aufdemkampe G: Physical exercise in cancer patients during and after medical treatment: a systematic review of randomized and controlled clinical trials. J Clin Oncol 2005, 23:3830-3842.

3. Cramp F, Daniel J: Exercise for the management of cancer-related fatigue in adults. Cochrane Database Syst Rev 2008, 16:CD006145.

4. Speed-Andrews AE, Courneya KS: Effects of exercise on quality of life and prognosis in cancer survivors. Curr Sports Med Rep 2009, 8:176-181.

5. Speck RM, Courneya KS, Mâsse LC, Duval S, Schmitz KH: An update of controlled physical activity trials in cancer survivors: a systematic review and meta-analysis. Cancer Surviv 2010.

6. Velthuis MJ, Agasi-Idenburg SC, Aufdemkampe G, Wittink HM: The Effect of physical exercise on cancer-related fatigue during cancer treatment: a meta-analysis of randomised controlled trials. Clin Oncol (R Coll Radiol) 2010.

7. Wiskemann J, Huber G: Physical exercise as adjuvant therapy for patients undergoing hematopoietic stem cell transplantation. Bone Marrow Transplant 2008, 41:321-329.

8. Manson JE, Greenland P, LaCroix AZ, Stefanick ML, Mouton CP, Oberman A, Perri MG, Sheps DS, Pettinger MB, Siscovick DS: Walking compared with vigorous exercise for the prevention of cardiovascular events in women. N Engl J Med 2002, 347:716-725.

9. McDonald CM, Widman L, Abresch RT, Walsh SA, Walsh DD: Utility of a step activity monitor for the measurement of daily ambulatory activity in children. Arch Phys Med Rehabil 2005, 86:793-801.

10. Tudor-Locke C, Bassett DR Jr: How many steps/day are enough? Preliminary pedometer indices for public health. Sports Med 2004, 34:1-8.

11. Brown JK, Byers T, Doyle C, Coumeya KS, Demark-Wahnefried W, Kushi LH, Rock CL, Aziz N, Bloch AS, Eldridge B, Hamilton K, Katzin C, Koonce A, Main J, Mobley C, Morra ME, Pierce MS, Sawyer KA, American Cancer Society: Nutrition and physical activity during and after cancer treatment: an American Cancer Society guide for informed choices. CA Cancer J Clin 2003, 53:268-291.

12. Busse ME, Pearson OR, Van Deursen R, Wiles CM: Quantified measurement of activity provides insight into motor function and recovery in neurological disease. J Neurol Neurosurg Psychiatry 2004, 75:884-888.

13. Lubans DR, Morgan PJ, Tudor-Locke C-Verhagen AP, de Vet HC, de Bie RA, Kessels AG, Boers M, Bouter LM, Knipschild PG: A systematic review of studies using pedometers to promote physical activity among youth. Prev Med 2009, 48:307-15.

14. Bravata DM, Smith-Spangler C, Sundaram V, Gienger AL, Lin N, Lewis R, Stave CD, Olkin I, Sirard JR: Using pedometers to increase physical activity and improve health: a systematic review. JAMA 2007, 21:2296-2304.

15. Tudor-Locke C, Washington TL, Hart TL: Expected values for steps/day in special populations. Prev Med 2009, 49:3-11.

16. de Bruin ED, Hartmann A, Uebelhart D, Murer K, Zijlstra W: Wearable systems for monitoring mobility related activities in older people; a systematic review. Clinical Rehabilitation 2008, 22:878-895.

17. Verhagen $A P$, de Vet $H C$, de Bie RA, Kessels AG, Boers M, Bouter LM, Knipschild PG: The Delphi list: a criteria list for quality assessment of randomized clinical trials for conducting systematic reviews developed by Delphi consensus. J Clin Epidemiol 1998, 51:1235-1241.

18. PEDro scale. [http://www.pedro.org.au/].

19. van Tulder M, Malmivaara A, Esmail R, Koes B: Exercise therapy for low back pain: A systematic review within the framework of the Cochrane collaboration back review group. Spine 2000, 25:2784-2796.

20. Landis J, Koch G: The measurement of observer agreement for categorical data. Biometrics 1977, 33:159-174.

21. Van Tulder M, Assendelft W, Koes B, Koes BW, Bouter LM: Method guidelines for systematic reviews in the Cochrane Collaboration Back Review Group for Spinal Disorders. Spine 1997, 22:2323-2330.

22. Moher D, Liberati A, Tetzlaff J, Altman DG, PRISMA Group: Preferred reporting items for systematic reviews and meta-analyses: the PRISMA statement. J Clin Epidemiol 2009, 62:1006-12

23. Kahn SR, Shrier I, Kearon C: Physical activity in patients with deep venous thrombosis: a systematic review. Thromb Res 2008, 122:763-773.

24. Irwin ML, Cadmus L, Alvarez-Reeves M, O'Neil M, Mierzejewski E, Latka R, Yu H, DiPietro L, Jones B, Tish Knobf M, Chung GC, Mayne ST: Recruiting and retaining breast cancer survivors into a randomized controlled exercise trial: the Yale Exercise and Survivorship Study. Cancer 2008, 112(11 Suppl):2593-2606.

25. Rogers LQ, Hopkins-Price P, Vicari S, Pamenter R, Courneya KS, Markwell S, Verhulst S, Hoelzer K, Naritoku C, Jones L, Dunnington G, Lanzotti V, Wynstra J, Shah L, Edson B, Graff A, Lowy M: A randomized trial to increase physical activity in breast cancer survivors. Med Sci Sports Exerc 2009, 41:935-946.

26. Vallance JK, Courneya KS, Plotnikoff RC, Yasui Y, Mackey JR: Randomized controlled trial of the effects of print materials and step pedometers on physical activity and quality of life in breast cancer survivors. J Clin Oncol 2007, 25:2352-2359.

27. Matthews CE, Wilcox S, Hanby CL, Der Ananian C, Heiney SP, Gebretsadik T, Shintani A: Evaluation of a 12-week home-based walking intervention for breast cancer survivors. Support Care Cancer 2007, 15:203-211.

28. Irwin ML, Alvarez-Reeves M, Cadmus L, Mierzejewski E, Mayne ST, Yu H, Chung GG, Jones B, Knobf MT, DiPietro L: Exercise improves body fat, lean mass, and bone mass in breast cancer survivors. Obesity (Silver Spring) 2009, 17:1534-1541.I.

29. Irwin ML, Varma K, Alvarez-Reeves M, Cadmus L, Wiley A, Chung GG, Dipietro L, Mayne ST, Yu H: Randomized controlled trial of aerobic exercise on insulin and insulin like growth factors in breast cancer survivors: the Yale Exercise and Survivorship study. Cancer Epidemiol Biomarkers Prev 2009, 18:306-313.

30. McNeely ML, Campbell KL, Rowe BH, Klassen TP, Mackey JR, Courneya KS: Effects of exercise on breast cancer patients and survivors: a systematic review and meta-analysis. CMAJ 2006, 175:34-41.

31. Maddocks M, Lewis M, Chauhan A, Manderson C, Hocknell J, Wilcock A: Randomized Controlled Pilot Study of Neuromuscular Electrical Stimulation of the Quadriceps in Patients with Non-Small Cell Lung Cancer. J Pain Symptom Manage 2009.

32. Sillen MJ, Speksnijder CM, Eterman RM, Janssen PP, Wagers SS, Wouters EF, Uszko-Lencer NH, Spruit MA: Effects of neuromuscular electrical stimulation of muscles of ambulation inpatients with chronic heart 
failure or COPD: a systematic review of the English-language literature. Chest 2009, 136:44-61.

33. Graupe D, Cerrel-Bazo H, Kern H, Carraro U: Walking performance, medical outcomes and patient training in FES of innervated muscles for ambulation by thoracic-level complete paraplegics. Neurol Res 2008 30:123-310.

34. Tudor-Locke C, Hatano Y, Pangrazi RP, Kang M: Revisiting "how many steps are enough?". Med Sci Sports Exerc 2008, 40(7 Suppl):537-543.

35. Holmes MD, Chen WY, Feskanich D, Kroenke CH, Colditz GA: Physical activity and survival after breast cancer diagnosis. JAMA 2005, 25:2479-2486.

36. Knols RH, de Bruin ED, Aufdemkampe G, Uebelhart D, Aaronson NK Reliability of ambulatory walking activity in patients with hematologic malignancies. Arch Phys Med Rehabil 2009, 90:58-65.38.

37. Vallance JK, Courneya KS, Plotnikoff RC, Mackey JR: Analyzing theoretical mechanisms of physical activity behavior change in breast cancer survivors: results from the activity promotion (ACTION) trial. Ann Behav Med 2008, 35:150-158.

38. Fishbein M, von Haeften I, Appleyard J: The role of theory in developing effective interventions: implications from Project SAFER. Psychol Health Med 2001, 6:223-238, Wood ME.

39. Rogers LQ, Shah P, Dunnington G, Greive A, Shanmugham A, Dawson B, Courneya KS: Social cognitive theory and physical activity during breast cancer treatment. Oncol Nurs Forum 2005, 32:807-815.

40. Furber S, Butler L, Phongsavan P, Mark A, Bauman A: Randomised controlled trial of a pedometer-based telephone intervention to increase physical activity among cardiac patients not attending cardiac rehabilitation. Patient Educ Couns 2009, 16.

\section{Pre-publication history}

The pre-publication history for this paper can be accessed here: http://www.biomedcentral.com/1471-2407/10/406/prepub

\section{doi:10.1186/1471-2407-10-406}

Cite this article as: Knols et al:: Physical activity interventions to improve daily walking activity in cancer survivors. BMC Cancer 2010 10:406.

\section{Submit your next manuscript to BioMed Central and take full advantage of:}

- Convenient online submission

- Thorough peer review

- No space constraints or color figure charges

- Immediate publication on acceptance

- Inclusion in PubMed, CAS, Scopus and Google Scholar

- Research which is freely available for redistribution 